\title{
FIRST REPORT ON THE OCCURRENCE AND SYMPTOMATOLOGY OF PHYLLODY DISEASE IN JUTE (Corchorus olitorius L.) AND ITS PLANT CHARACTERISTICS IN TURKEY
}

\author{
M. Ilhan CAGIRGAN ${ }^{I^{*}}$, Hasan TOPUZ ${ }^{1}$, Nalla MBAYE ${ }^{1,2}$, R. Soner SILME ${ }^{1,3}$ \\ ${ }^{1}$ Antalya Mutation Project, Department of Field Crops, Faculty of Agriculture, Akdeniz University, \\ Antalya, TURKEY \\ ${ }^{2}$ Université Cheikh Anta Diop, Faculté des Sciences et Techniques, Département de Biologie Végétale, \\ Dakar-Fann, SENEGAL \\ ${ }^{3}$ Istanbul University, Scientific Research Projects, Istanbul, TURKEY \\ *Corresponding author: cagirgan@akdeniz.edu.tr
}

Received: 21.04.2014

\begin{abstract}
Although jute (Corchorus olitorius L.) is treated as a weed in Turkey, it is cultivated and harvested for its fiber, tender shoots, and leaves in Africa and Asia. We report the occurrence and symptomatology of phyllody disease in jute observed for the first time in 2010 during our studies focusing on sesame phyllody in an experimental field at the Akdeniz University Campus, Antalya, Turkey. The disease was also observed in the following two years, 2011 and 2012. In the top of the infected jute plant, the internodes were shortened which resulted a cluster of leaves in smaller size than the normal ones, and the leaves were crinkled as well as turned to yellowing and leathery-looking. Additionally, the large leaves accumulated more anthocyanin in their margins. The floral organs abnormally developed into leafy structures; and ovaries at the symptomatic part enlarged but stamens and filaments did not show any symptoms. There was neither proliferation of the branches nor needle-like shape of the leaves in our case. Jute and sesame seeds started germination synchronously, and looked similar at the cotyledonary stage. Wild plants or weeds deserve a particular attention for disease development or inoculum build-up in cultivated crops. Considering the voluntary nature, jute may be an alternative for biofuel production. Also, the similarity in developmental stages of jute and sesame suggests that they might be affected by the same phytoplasma. To verify this, molecular analyses have been started.
\end{abstract}

Key words: Biofuel, inoculum, molokhia, phytoplasmas, reservoir, wild.

\section{INTRODUCTION}

Jute (Corchorus olitorius L.) $2 n=14,28$ belongs to Malvaceae (Tiliaceae). It was originated from South China and introduced to India and Pakistan. Wild types are found in India, China, Australia and Africa. It occupies through Tropical Desert to Wet Forest Life Zones and it tolerates annual precipitation of 40 to 429 $\mathrm{mm}$, annual temperature of 16.8 to $27.5^{\circ} \mathrm{C}$ and $\mathrm{pH}$ of 4.5 to 8.2 (Duke, 1983).

It is not only a well-known fiber crop, but also an important green leafy vegetable which its leaves and tender shoots are eaten in some tropical countries of the South America, Africa and Asia including Japan, the Philippines, Malaysia and the Caribbean, India, Bangladesh and Cyprus. It is cultivated in many countries with an economic impact in South-Western, West parts of Africa and Indian peninsula, especially in Ghana, Nigeria and Sierra Leone (Tulio et al., 2002).
Its leaves have medicinal uses for cystitis, dysuria, fever, gonorrhea, ascites, pain, piles, and tumors (Negm et al., 1980; Duke, 1983). Also, extracts of the plant were determined to have antibacterial and antifungal properties (Ilhan et al., 2007). The folic acid content is substantially higher than that of other folacin-rich vegetables (Duke, 1983). Jute is a crop plant of tropic and subtropic climates. Jute is not grown as a crop in Turkey. It grows as a weed in natural habitat and fields and also observed in the southern provinces such as Antalya, Adana and Hatay of the Mediterranean Region of Turkey (Incekara, 1979).

Phyllody is caused by phytoplasmas (mycoplasma-like organisms) discovered in 1967 (Doi et al., 1967) and causes devastating yield losses in diverse low- and highvalue crops worldwide (Nakashima et al., 1995; Lee et al., 2000; Bertaccini, 2007; Wongkaew, 2013). Phytoplasmas are described as small pleiomorphic bacteria with single membrane, belongs to the class Mollicutes (Woese, 1987; Weisburg et al., 1989). Phytoplasmas cannot be cultured outside their hosts in cell-free artificial culture media. 
They are phloem-limited (Doi et al., 1967; Whitcomb and Tully, 1989) and obligate symbionts of plants and insects. Insect vectors of phytoplasmas are classified in the Order Hemiptera mostly leafhoppers, planthoppers and psyllids (Weintraub and Beanland, 2006) and feed on the phloem tissues of infected plants. Although phyllody reported in different economically important crops there is no detailed report regarding jute phyllody, except similar publications by Rabindran et al., (1988a,b). Jute phyllody was noticed in sesame fields in Thailand (Wongkaew, 2013). The insect vectors affect the host range of phytoplasmas. A major antigenic protein that phytoplasmas have, makes up the majority of their cell surface proteins, and it is discovered that this protein has interaction with microfilament complexes of the intestinal muscles of insects. This protein is believed to be a major factor for both transmission and infection (Suzuki et al., 2006; Hoshi et al., 2007). Different insects were identified as vectors of phyllody disease in different plants. Transmission of sesame phyllody by Orosius albicinctus (Distant) [=orientalis (Matsumura)] in India, Israel, Iran, and Turkey (Klein, 1977; Kolte, 1985; Baspinar et al., 1993; Sertkaya et al., 2007; Ozdemir et al., 2013). Also transmission through grafting and vegetative propagation (cuttings, storage tubers, rhizomes or bulbs) are described but not transmitted via either the plant's sap or the seed (Lee and Davis, 1992; Fletcher et al., 1998).

The main symptoms of infected plants are reported as virescence, phyllody, proliferation (witches-broom; a wild, erratic, broom-like growth at the ends of shoots, stems or branches), yellowing, reduction in leaf size, overall stunted growth, leaf-roll, bunchy appearance of growth at the ends of the stems, big bud (floral gigantism), and a generalized decline (stunting, die-back of twigs and unseasonal yellowing or reddening of leaves) (Lee et al., 2000; Bertaccini, 2007; Cagirgan et al., 2013).

Phyllody was reported in field crops, fruits, vegetables and ornamentals belong to different families and species such as sesame (Sesamum indicum L.), safflower (Carthamus tinctorius L.), peanut (Arachis hypogaea L.), jute (Corchorus olitorius L.), tomato (Solanum lycopersicum L.), pepper (Capsicum annuum L.), eggplant (Solanum melongena L.), chickpea (Cicer arietinum L.), mango (Mangifera indica L.), citrus (Citrus spp.), periwinkle (Catharantus roseus (L.) G. Don.), geranium (Pelargonium spp.), and rose (Rosa indica Redout \& Thory) to mention among others (Rabindran et al., 1988a,b; Bertaccini, 2007; Borroto Fernandez et al., 2007; Akhtar et al., 2009a,b; Cagirgan et al., 2013; Ertunc, 2013; Ozdemir et al., 2013; Wongkaew, 2013).

It was determined by Rahman and Khan (2010) that the jute agroecosystem in India supports large number of natural enemies of crop pests and their importance in integrated approach for management of pests of jute is also possible. However, the incidence of different pests in jute crop and the role of weather factors affecting vector populations have not been investigated in detail. Whereas the disease could potentially be managed indirectly by spraying systemic insecticides to kill the insect vectors, but the use of resistant germplasm is the best option for enviromental causes and reducing the production costs.

Cagirgan et al. (2013) grew a sesame elite genotype to avoid outcrossing in a location where there is no sesame cultivation but observed sesame phyllody. Considering no seed transmittance of the sesame phyllody, this observation underlines the importance of weeds or wild plants available at the neighborhood as an inoculum reservoir for the vectors to transmit the phytoplasma. Phytoplasma diseases in wild plants have been reported rarely. They should be considered and paid attention for disease development and inoculum build-up (Borroto Fernandez et al., 2007).

The aims of the study were 1) to report the first occurrence, and (2) to describe the symptomatology of the phyllody disease in jute grown as weed in a sesame field, and to determine plant characteristics of the jute plant.

\section{MATERIALS AND METHODS}

\section{Enviromental and growing conditions}

The study was carried out in the experimental field at Akdeniz University Campus, Antalya, Turkey. The altitude of the research field from sea level is approximate $19 \mathrm{~m}$ and is located at $36^{\circ} 53.829 \mathrm{~N}$ and $30^{\circ} 38.552 \mathrm{E}$. The study area has a typical Mediterranean climate with hot and dry summers, and mild winters. Rainfall mostly occurs during winter period as shown in Figure 1, which was drawn according to Walter (1970). The soil depth is low which formed on a travertine material and cleared after picking up the rocks. However, some part of the field shows different characteristics reflected by the carriedover soil which introduced many species of weeds which are not natural habitat of the field. The physical and chemical characteristics of the soil are given in Table 1.

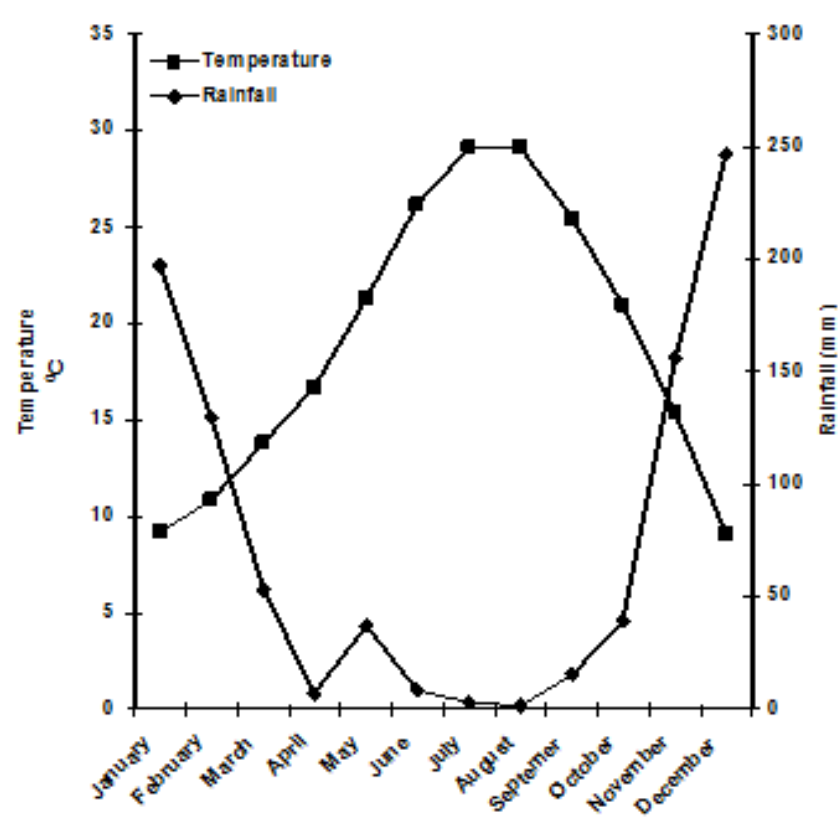

Figure 1. Climate diagram for Antalya city center for 10 years (2001-2010). 
Table 1. Soil characteristics of the field

\begin{tabular}{lll}
\hline Characteristics & Unit & Value \\
\hline $\mathrm{pH}$ & & 8.27 \\
$\mathrm{EC}($ Salt $)$ & mmhos/cm & 1.7 \\
$\mathrm{CaCO}_{3}$ & $\%$ & 42.7 \\
Organic Matter & $\%$ & 1.0 \\
Total N & $\%$ & 0.08 \\
Available P & $\%$ & 0.0163 \\
Available K & $\%$ & 0.0080 \\
Available Ca & $\%$ & 0.0609 \\
Available $\mathrm{Mg}$ & $\%$ & 0.0053 \\
Available Fe & $\mathrm{ppm}$ & 7.6 \\
Available $\mathrm{Mn}$ & $\mathrm{ppm}$ & 13.00 \\
\hline
\end{tabular}

Sesame has been grown for 19 years in the field as a summer crop under intensive management (Silme and Cagirgan, 2010) rotated by a winter crop, mostly barley (Hordeum vulgare L.). Jute plants were observed as weed among sesame nurseries. When we focused on studying sesame phyllody disease which was observed every year at any frequency, one voluntary jute plant which showed phyllody symptoms was isolated and studied symptomatically. Since all the weeds were controlled by hand and mechanically, we did not obtain useful data regarding incidence of the phyllody affecting jute. Despite of the weed control, jute seeds kept germination and regrowing (Figure 2f,g) in a short time. Thereupon the spectrum and occurrence of the weeds in the field were presented in Table 2.

Table 2. Weeds observed in the field

\begin{tabular}{|c|c|}
\hline Name & Weeds/m² \\
\hline $\begin{array}{l}\text { Nalta jute } \\
\text { (Corchorus olitorius } \mathrm{L} . \text { ) }\end{array}$ & 4 \\
\hline $\begin{array}{l}\text { Nutgrass } \\
\text { (Cyperus rotundus } \mathrm{L} . \text { ) }\end{array}$ & 5 \\
\hline $\begin{array}{l}\text { Cocklebur } \\
\text { (Xanthium strumarium L.) }\end{array}$ & 3 \\
\hline $\begin{array}{l}\text { Johnson grass } \\
\text { (Sorghum halepense L. Pers.) }\end{array}$ & 0.4 \\
\hline
\end{tabular}

\section{Plant characteristics}

The plant characteristics of the normal-looking jute plants were sampled in 2011 and 2012 and following data were recorded: Plant height $(\mathrm{cm})$, number of branches, capsule length $(\mathrm{mm})$, number of capsules per plant, number of seeds per capsule, 1000-seed weight $(\mathrm{g})$ and seed weight per plant. Thereafter simple statistics for each year were calculated using the MINITAB statistical software (MINITAB Inc., 1997).

\section{RESULTS AND DISCUSSION}

\section{Symptomatology}

A voluntarily grown jute plant in the sesame nursery, which shown typical phyllody symptoms, was observed in 2010 (Figure 2a), and others in the following two years in comparison to the healthy one (Figure 2d). In the top of the plant, internodes were shortened; number of leaves increased in smaller size than the normal, and crinkled as well as turned to yellowing and leathery-looking. In addition to these symptoms, the large leaves showed more anthocyanin in their margins. The development of floral organs and the branching retarded at this part of the plants showing the aforementioned symptoms. Where available, ovaries at this symptomatic part enlarged and grew very big (Figure 2b,c) but stamens and filaments did not show any symptoms (Figure 2c). There is only one study of jute phyllody by Rabindran et al. (1988a,b) stating that the leaves were crinkled, leathery, and at the top of the plant, needle-like. They also added that floral organs were deformed, internodes were shortened; and branches proliferated. Although there were some similarities to our case such as crinkled and leathery leaves and shortened internodes, there were no any proliferation of the branches and needle-like shape of the leaves in our case. Rather, branching was lost in the symptomatic part of the infected plant but the leaves resulted in a cluster-looking (Figure 2a).

Jute has never been cultivated previously in the field which was opened to cultivation some 19 years ago by clearing rocks in the travertine land of the university campus. Voluntary jute plants have been observed in the field since the sesame cultivation started. In every season sesame phyllody has noticed at any rate. Symptomatology and incidence of sesame phyllody in the same field was reported recently by Cagirgan et al. (2013) regarding climate change and variability.

The authors reported main three types of sesame phyllody, i.e., virescence, phyllody and proliferation (witches' broom), but the latter was less-frequent during the study. However, in the season of 2013, the proliferated symptomatic plants turned to be highest in frequency. Appearance of different symptom types is believed to be related with the time of infection (Klein, 1977; Akhtar et.al., 2009a; Cagirgan et al., 2013).

Although jute is distributed pantropically, it is considered more often a weed than a cultivated species. It is particularly a serious weed in Australia, Egypt, Mozambique, the Philippinnes, Senegal and Thailand (Duke, 1983) and a common weed in the Mediterranean Region of Turkey (Incekara, 1979).

During the study, we observed that four Corchorus olitorius $\mathrm{L}$. per $\mathrm{m}^{2}$ (Table 2) after hand and mechanical weeding in and around the sesame breeding nursery.

Regarding wild plants, reports on phytoplasma diseases are infrequent and in the majority of cases the disease has not been considered or subjected to spraying, e.g. herbicide treatments (Borroto Fernandez et al., 2007). As in the cases where a high number of plants appeared with typical symptoms attributed normally to phytoplasma infection. Weed species deserve particular attention in terms of inoculum build-up, epidemy and disease development as well as the migration of pathogens from domesticated plants and into the weeds. Cagirgan et al. (2013) reported phyllody in sesame in a region where there was no sesame acreage, which underlines importance of the neighbouring wild host of the phytoplasmas infecting sesame. 

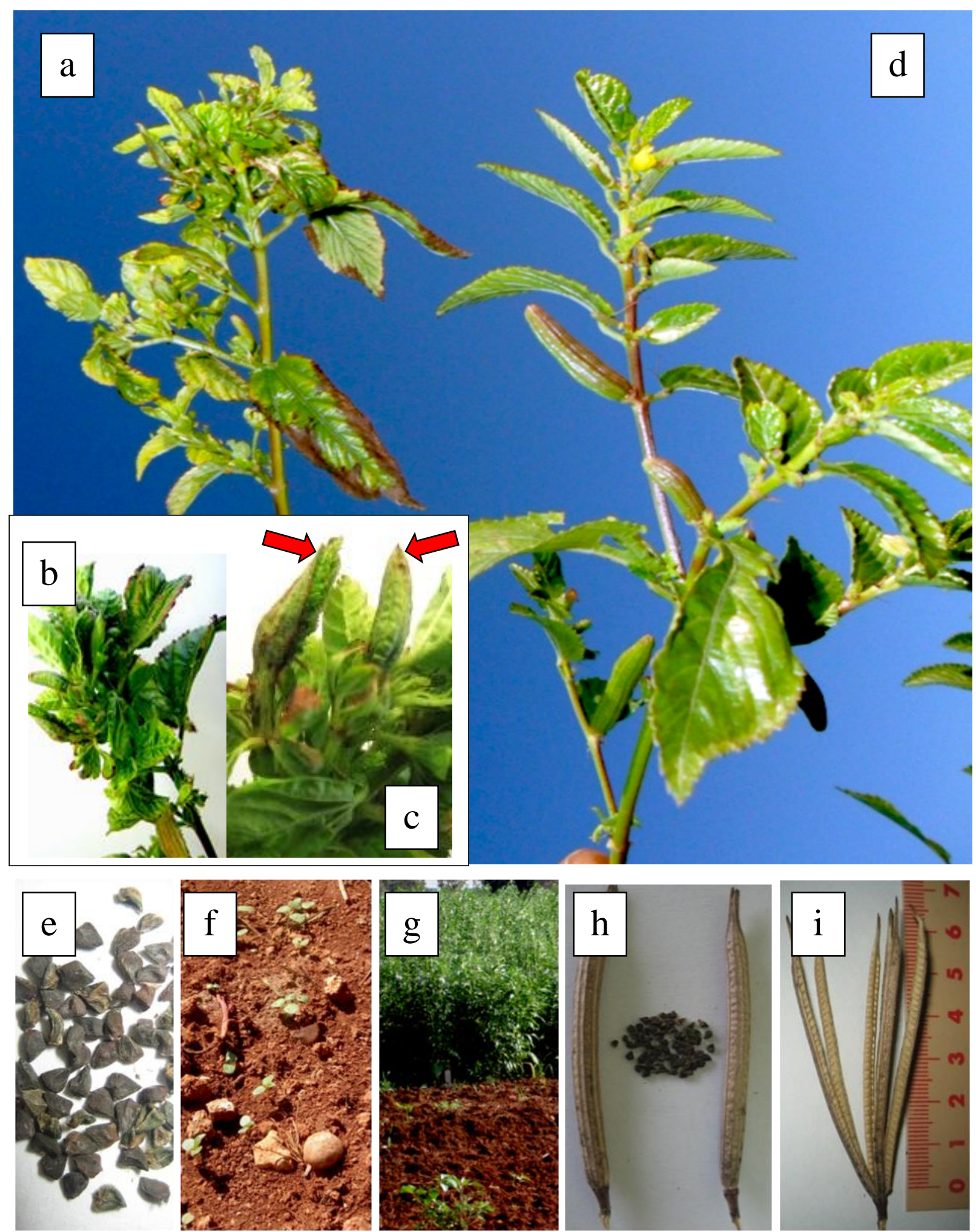

Figure 2. The jute plant with phyllody (a), close up to the symptom (b), symptomatic enlarged ovary with phylloid ovules (c), in comparison to a normal healthy plant with yellow flower (d). Shapeless black seed (e), cotyledonary stage (f) and voluntary jute plants (front) as weeds, and sesame crop (behind) (g). Mature fruits and comparative seed size (h) and an open capsule with 6 carpels (i). 
Rabindran et al. (1988a) reported that the disease could be graft-transmitted to Corchorus olitorius but not to Sesamum indicum or Crotalaria juncea. It is thought that insect vectors may transmit the disease mainly as mentioned before. Effective management of diseases caused by phytoplasmas requires identification of their insect vectors (Bertaccini, 2007; Kakizawa et al., 2010; Wongkaew, 2013). Regarding the question whether or not there is any relation between the sesame phyllody and the jute phyllody, it is not possible to answer this question at the moment. Despite the graft-transmitting report by Rabindran et al. (1988a), we speculate that sesame phytoplasmas might infect jute as well, considering the disease symptoms, vectors, common environment and agroecological similarities between the two species. Detection and identification of phytoplasmas is of course necessary for accurate disease diagnosis including both host systems, i.e. in plant species, where phytoplasmas are localized in phloem cells, and in insect vectors. Molecular studies have been started to clearify phytoplasma relations between jute and sesame.

Wilson et al. (2001) used molecular techniques to investigate the little-known characteristics of phytoplasmas in the semi-arid tropics of northern Australia in sesame, mung bean and peanut crops, and in adjacent non-crop species and reported five new records of plant species associated with phytoplasma diseases. No phytoplasmas were associated with fasciation but four phytoplasma strains were linked with other symptoms. These findings showed that adjacent non-crop species had the potential to function as reservoirs of phytoplasma disease for crop species. Also it was confirmed by Borroto Fernandez et al. (2007) that phytoplasma infected plants in forests may role as a reservoir.

Table 3. Simple statistics for plant characters of jute grown as weed in a sesame field in 2011 and 2012

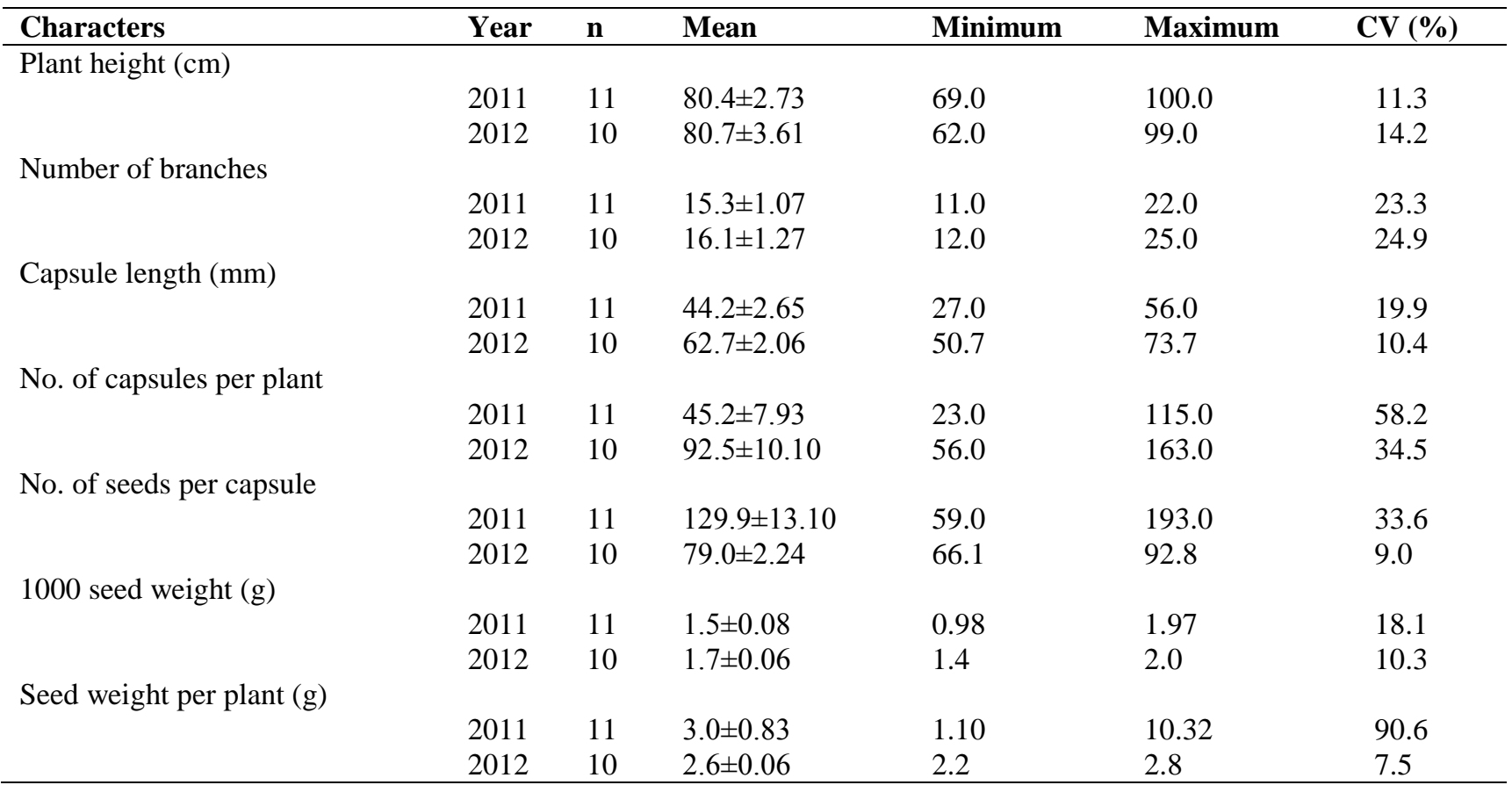

n: number of plants measured, CV (\%): Coefficient of variation

\section{Plant characteristics}

The seeds of jute plant were dark black, small and shapeless (Figure 2e), which started germination with sesame in the field of Akdeniz University Campus. It was very similar to sesame at cotyledonary stage, but distinguished with the available longer and serrated third leaflet (Figure 2f). They germinated constantly and were grown voluntarily in and around the sesame nursery even after continual weeding (Figure $2 \mathrm{~g}$ ). Plant height at maturity altered from $62 \mathrm{~cm}$ to $100 \mathrm{~cm}$ with multibranches (11-25) in 2011 and 2012 (Table 3). The main stem and branches contained anthocyanin apparently. It had dark green leaves nearly 5-10 cm long, $2-5 \mathrm{~cm}$ broad and serrated (Figure 2d). Its small yellow flowers had peduncle which was shorter than the petiole. The flower had 10 or more than 10 stamens surrounding the ovary. Stigma consisted of 5 partitions. It flowered about 40 days after germination. Number of capsules ranged between 23 and 163. Capsule length was 27.0-73.7 mm, disunited and linear. Number of seeds per capsule changed between 59.0 and 193.0. The mean of 1000-seed weight was $1.5 \mathrm{~g}$ and $1.7 \mathrm{~g}$ in both years, respectively (Table 3 ).

In conclusion, currently, there are no appropriate measures for directly controlling phytoplasma-caused disease. Phyllody may cause a direct loss of economic value, may pose a serious threat of their spread on the other economically important crops growing in the neighborhood of the infected plant species. Both insect vectors and alternative hosts are factors determining the maintenance of phytoplasma in the environment. Weeds 
or wild plants in general should be considered as inoculum reservoir. Although jute is considered as a fiber crop, it is also considered as vegetable for its tender green leaves with growing concerns of food security. It presents cheap sources of vitamins, minerals and has a potential for reducing food insecurity in the underdeveloped part of the world. Furthermore, it offers a different choice of vegetables to the western cuisine. Thanks to its low input requiring and voluntarily growing nature, it might also be considered as a biomass for biofuel production in marginal areas. Although the symptoms have been identified in this article the molecular detection of the phytoplasma and disease incidence in jute remain a further step to succeed.

\section{ACKNOWLEDGEMENTS}

We express our gratitude to Prof. Dr. Huseyin SUMBUL of Akdeniz University for taxonomic description of jute plant. Also we are thankful to Meteorological Station of Antalya for providing the climatical data.

\section{LITERATURE CITED}

Akhtar, K.P., G. Sarwar, M. Dickinson, M. Ahmad, M.A. Haq, S. Hameed and M.J. Iqbal. 2009a. Sesame Phyllody Disease: Symptomatology, etiology and transmission in Pakistan. Turk. J. Agri. For. 33:477-486.

Akhtar, K.P., T.M. Shah, B.M. Atta, M. Dickinson, J. Hodgetts, R.A. Khan, M.A. Haq and S. Hameed. 2009b. Symptomatology, etiology and transmission of chickpea phyllody disease in Pakistan. J. Plant Pathol. 91:649-653.

Baspinar H., S. Korkmaz, N. Onelge, A. Cinar, N. Uygun and U. Kersting, 1993. Studies on citrus stubborn disease and sesame phyllody in sesame and their related leafhopper vectors. J. Turk. Phytopath. 22:1-8.

Bertaccini, A. 2007. Phytoplasmas: Diversity, taxonomy and epidemiology. Front. Biosci. 12:673-689.

Borroto Fernandez, E.G., A. Calari, V. Hanzer, H. Katinger, A. Bertaccini and M. Laimer. 2007. Phytoplasma infected plants in Austrian forests: role as a reservoir? Bull. Insectology 60(2): 391-392.

Cagirgan M.I., N. Mbaye, R.S. Silme, N. Ouedraogo and H. Topuz. 2013. The impact of climate variability on occurrence of sesame phyllody and symptomatology of the disease in a Mediterranean environment. Turk. J. Field Crops 18(1): 101-108.

Doi, Y., M. Teranaka, K. Yora and H. Asuyama. 1967. Mycoplasma- or PLT group-like microorganisms found in the phloem elements of plants infected with mulberry dwarf, potato witches' broom, aster yellows or paulownia witches' broom. Ann. Phytopathol. Soc. Jpn. 33 (4):259-266.

Duke, J.A. 1983. Handbook of Energy Crops. https://www.hort.purdue.edu/newcrop/duke_energy/Corchor us_olitorius.html (accessed on 21 April 2014).

Ertunc, F. 2013. A new threat for Turkish horticulture: phytoplasma diseases and their vectors. Ankara Üniv. Vet. Fak. Derg. 60: 221-224.

Fletcher, J., A. Wayadande, U. Melcher and F. Ye. 1998. The phytopathogenic mollicute-insect vector interface: a closer look. Phytopathology. 88:1351-1358.

Hoshi A., Y. Ishii, S. Kakizawa, K. Oshima and S. Namba. 2007. Host parasite interaction of phytoplasmas from a molecular biological perspective. Bull. Insectology 60: 105-107.
Ilhan, S., F. Savaroglu and F. Colak. 2007. Antibacterial and antifungal activity of Corchorus olitorius L. (Molokhia) Extracts. Int. J. Nat. Eng. Sci. 1(3): 59-61.

Incekara, F. 1979. Industrial Crops and their Breeding: Ege University, Faculty of Agriculture Publi. Number 3-65. (in Turkish)

Kakizawa, S., K. Oshima, and S. Namba. 2010. Functional genomics of phytoplasmas. In: Phytoplasmas: genomes, plant hosts and vectors, eds. Weintraub P.G., Jones P., 3750, CAB International, Wallingford (UK).

Klein, M. 1977. Sesame phyllody in Israel. Phytopath. Z. 88:165-171.

Kolte, S.J. 1985. Diseases of Annual Edible Oil Seed Crops.Vol II. CRC Press.

Lee, I.M, R.E. Davis and D.E. Gundersen-Rindal. 2000. Phytoplasma: phytopathogenic mollicutes. Ann. Rev. Microbiol. 54:221-255.

Lee, I.M. and R.E. Davis. 1992. Mycoplasmas which infect plants and insects. In: Mycoplasmas: Molecular Biology and Pathogenesis, ed. Maniloff J., McElhaney R.N., Finch L.R., Baseman J.B., 379-390, American Society of Microbiology, Washington (DC).

MINITAB Inc., 1997. MINITAB Statistical Software. Release 12 for Windows. USA.

Nakashima K., T. Hayashi, W. Chaleeprom, P. Wongkaev and P. Sirithorn. 1995. Detection of DNA of phytoplasmas associated with phyllody disease of sesame in Thailand, Ann. Phytopathol. Soc. Jpn. 61:519-528.

Negm S., O. EI-Shabrawy, M. Arbid and A.S. Radwan. 1980. Toxicological study of the different organs of Corchorusolitorius L. plant with special reference to their cardiac glycosides content. Zeitsc.Ernaehrungsw. 19(1):2832.

Ozdemir, Z., H. Topuz and M.I. Cagirgan. 2013. Identification of sesame phyllody phytoplasmas and incidence of sesame phyllody disease in Antalya, Turkey. (ICPP 2013 10th International Congress of Plant Pathology 25-30 August 2013, Beijing, China) Acta Phytopathol. Sinica 43 (supplement): 204

Rabindran, R., K. Pillayarsamy, B. Subbalakshmi, R. Jeyarajan and S. Doraiswamy. 1988a. Phyllody - a new disease of jute (Corchorus olitorius L.). http://www.cabdirect.org/ abstracts/ 19891136690.html?resultNumber=0\&q=rabindran+jute (Accessed April 24, 2014).

Rabindran, R., K.P. Samy, B. Subbalakshmi, R. Jeyarajan and S. Doraiswamy. 1988b. Phyllody - a new disease of jute (Corchorus olitorius L). http://www.cabdirect.org/ abstracts/19901143228.html?resultNumber=1\&q=rabindran +jute (Accessed April 24, 2014).

Rahman, S. and M.R. Khan.2010. Integrated management approach for control of the pest complex of olitorius jute, Corchorus olitorius. J. Plant Prot. Res. 50(3): 340-346.

Sertkaya, G., M. Martini, R. Musetti and R. Osler. 2007. Detection and molecular characterization of phytoplasmas infecting sesame and solanaceous crops in Turkey. Bull. Insectology 60:141-142.

Silme, R.S. and M.I. Cagirgan. 2010. Screening for resistance to fusarium wilt in induced mutants and world collection of sesame under intensive management. Turk. J. Field Crops. 15(1): 89-93.

Suzuki S., K. Oshima, S. Kakizawa, R. Arashida, H.Y. Jung, Y. Yamaji, H. Nishigawa, M. Ugaki and S. Namba, 2006. Interaction between the membrane protein of a pathogen and insect microfilament complex determines insect-vector specificity. Proc. Nat. Acad. Sci. USA 103: 4252-4257.

Tulio, A.Z., Jr. K. Ose, K. Chachin and Y. Ueda. 2002. Effects of storage temperatures on the postharvest quality of jute 
leaves (Corchorus olitorius L.). Postharvest Biol.Technol. 26: 329-338.

Walter, H., 1970. Vegetationszonen und Klima. Eugen Ulmer, Stuttgart.

Weintraub, P.G. and L. Beanland. 2006. Insect vectors of phytoplasmas. Annu. Rev. Entomol. 51:91-111.

Weisburg, W.G., J.G. Tully, D.L. Rose, J.P. Petzel, H. Oyaizu, D. Yang, L. Mandelco, J. Sechrest, T.G. Lawrence, J. Van Etten, J. Maniloff and C.R. Woese, 1989. A phylogenetic analysis of the mycoplasmas: basis for their classification. J. Bacteriol. 171:6455-6467.
Whitcomb, R.F. and J.G. Tully. 1989. The Mycoplasmas. Vol. 5. Academic Press, San Diego, CA.

Wilson, D.K., R. Blanche and K.S. Gibb. 2001. Phytoplasmas and disease symptoms of crops and weeds in the semi-arid tropics of the Northern Territory, Australia. Australas. Plant Path. 30:159-163.

Woese, C.R. 1987. Bacterial evolution. Microbiol.Rev. 51:221271.

Wongkaew, P. 2013. Plant diseases caused by phytoplasma. Biosensor Technology for Sustainable Development Research Group, Khon Kaen University Publishing, Klungnanawittaya Press Co.Ltd.,Khon Kaen, Thailand. 